for Berry's Study Abroad in Egypt program, and the coordinator of the Middle Eastern Studies major, a part of the College's Interdisciplinary Studies Program.

An intelligent, honest, hard-working, gentle, and compassionate individual, Johnson touched the lives of those people who had the good fortune to know her. Her death at such a young age is an immeasurable loss and she is profoundly missed by her family, colleagues, and students. Johnson is survived by her parents, Dennis and Paula Johnson; two sisters, Laura and Amanda; and five nephews.

Christy Snider Berry College

\title{
Aryeh Shmuelevitz (1932-2005)
}

Professor Aryeh Shmuelevitz passed away on 20 January, 2005, on his way to an academic conference at Tel Aviv University. The unexpected death of Shmuelevitz was a shock to his family, friends and colleagues, but it was hardly surprising that it occurred at the university. As one of his long-time colleagues described during the funeral at Kibbutz Einat on 21 January, "Aryeh was the continuous memory of the department," a figure that was ever present in the halls of academia since the 1950s.

Professor Aryeh Shmuelevitz was born in 1932 in the Yavniel farming community in the Galilee. He graduated from the Hebrew University in Jerusalem, earning his B.A. in Contemporary Middle East Studies and Modern History, in 1956, and his M.A. in the History of Islamic Countries and the History of Islamic Civilization, in 1960. His thesis was titled "Sultan Selim 1, 1512-20, as reflected in Elijah Capsali's Chronicle on Ottoman History," under the guidance of Professor Uriel Heyd.

His Ph.D. was awarded from the University of Wisconsin, Madison, in 1981. Its title was "Administrative, Economic, Legal and Social Relations in the Ottoman Empire in the Late $15^{\text {th }}$ and $16^{\text {th }}$ Centuries: The Case of the Jewish Community." Long before he completed his doctorate, Professor Shmuelevitz was lecturing at Tel Aviv University. He began lecturing in 1964, was one of the founders of the Shiloah Center for Middle Eastern and African Studies (renamed the Dayan Center in 1983), and became a Professor in the Department of Middle Eastern and African History at Tel Aviv University. Aryeh was a visiting professor, on various occasions, in French, Turkish, Japanese and American universities.

In addition to dozens of articles in academic journals and proceedings, perhaps the most important academic contribution of Professor Shmuelevitz was the editing and annotation of Seder Eliyahu Zuta by Rabbi Eliahu Capsali, on the history of the Ottoman and Venetian empires in the $17^{\text {th }}$ century. Aryeh also researched and wrote on contemporary Turkey and Iran and followed with great interest the role of religion in modern politics of the Middle East. 
Shmuelevitz served a number of times as the head of the department, was head of the Special Programs of Tel Aviv University, and was among the founders of the Tel Aviv-Jaffa Academic College. Aryeh was also the director of the Project for the Integration of the Oriental Jewish Heritage, from 1982-1991.

One of Aryeh's most notable legacies is the number of graduate students he supervised, both for their M.A. and Ph.D. theses, at Tel Aviv University and at Bar Ilan University. This was both a reflection of his dedication to scholarship, as well as his commitment to his students. Indeed, one of the traits his students, as well as colleagues, loved about Aryeh was his openness, whether it was to new ideas, or simply his willingness to listen and offer sound guidance and assistance. He will be deeply missed. Blessed be his memory.

Anat Lapidot-Firillas Harvard University

\section{Şinasi Tekin (1933-2004)}

On September 16, 2004, Sinasi Tekin died suddenly in Istanbul. Born in the village of Karagöz in the Balekesir district of southeastern Turkey in 1933, he attended high school in Istanbul and then studied Turkish language and literature in the Faculty of Literature at Istanbul University. In 1953 he went to Hamburg to study Old Uyghur with the doyenne of the field, Annemarie von Gabin, and completed his degree in 1958. After several teaching positions, including a time at Atatürk University in Erzurum, in 1965 he was invited to Harvard University, where he taught Old Uyghur, Ottoman, and Turcology, with a one-year leave to perform his military service in Turkey at the age of 45 .

Indefatigable in his efforts to promote the study of Turkology, Şinasi Bey made many significant contributions to the field, not the least of which was his founding and editorship, in collaboration with his wife, Gönül Alpay Tekin, of the Journal of Turkish Studies, now in its twenty-eighth year, and of a very successful companion series, Sources of Oriental Languages and Literatures, which has published more than fifty texts, studies, and translations of literature by or about Turks. In 1971 he published the $15^{\text {th }}$ century Menahicuil-insa, the oldest known manual on Ottoman composition. In 1993 he published a study of orthography, paper, and watermarks for Old Uyghur manuscripts, Eski Türklerde yazı, kâğt ve kâğt damgaları. In 2001 he published a collection of studies on Turkic etymology, İtikakçmm kössesi: Türk dilinde kelimelerin ve eklerin hayatı üzerine denemeler.

In 1997 he founded the Harvard Ottoman Summer School on Cunda Island in Ayvalık in collaboration initially with Uludağ University in Bursa and later with Koç University in Istanbul. Ottoman Summer School flourished for eight years under his direction and has had more than a hundred participants, all of whom will remember 